\title{
TECHNOLOGY OF COUPLED PERMEABILITY ENHANCEMENT OF HYDRAULIC PUNCHING AND DEEP-HOLE PRE-SPLITTING BLASTING IN A "THREE-SOFT" COAL SEAM
}

\author{
IZBOLJŠANJE PREPUSTNOSTI TREH MEHKIH PLASTI \\ PREMOGA Z ZDRUŽEVANJEM TEHNOLOGIJ HIDRAVLIČNEGA \\ PREBIJANJA IN MINIRANJA GLOBOKIH VRTIN
}

\author{
Pu Li ${ }^{1,2}$, Xiaodong Zhang ${ }^{1,3}$, Hui Li ${ }^{*}$ \\ ${ }^{1}$ School of Energy Science and Engineering, Henan Polytechnic University, Henan Province, Jiaozuo 454000, China \\ 2Zhengzhou Coal Industry (Group) Corporation Ltd, No. 188 Zhongyuan West Road, Zhongyuan District, Zhengzhou City, \\ Zhengzhou 450042, China \\ ${ }^{3}$ Collaborative Innovation Center of Coal-Bed Methane and Shale Gas for Central Plains Economic Region, Henan Province, \\ Jiaozuo 454000, China \\ ${ }^{4}$ School of Safety Science and Engineering, Henan Polytechnic University, Henan Province, Jiaozuo 454000, China
}

Prejem rokopisa - received: 2020-05-08; sprejem za objavo - accepted for publication: 2020-10-26

doi:10.17222/mit.2020.075

\begin{abstract}
Aiming at the problems of poor gas permeability, serious difficulty in gas extraction and low pre-extraction efficiency of the "three-soft" coal seam in the Zhengzhou mining area, a co-penetration technology of hydraulic punching and deep-hole pre-splitting blasting is put forward, and the mechanism of the co-penetration of hydraulic punching and deep-hole pre-cracking blasting is analyzed. Based on the theory of explosive dynamics and fracture mechanics, a numerical simulation method was adopted to study the stress distribution and propagation law of blast cracks in coal for different spaces between a blast hole and control extraction hole, and the reasonable space between the two blast holes is determined to be $4 \mathrm{~m}$. Through a field test of the Zhengzhou Coal Group GC Coal Mine, No. 188 Zhongyuan West Road, Zhongyuan District, Zhengzhou City, it is shown that the penetration effect after pre-cracking blasting is significant, the average and maximum purity of the gas extraction in the adjacent four groups after blasting reach $0.065 \mathrm{~m}^{3} / \mathrm{min}$ and $0.11 \mathrm{~m}^{3} / \mathrm{min}$, respectively, which is 2.5 and 5.5 times more than before blasting, and the permeability of the coal body near the blast hole reaches $2.47 \mathrm{~m}^{2} /(\mathrm{Mpa} 2 \cdot \mathrm{d})$, which is 466 times higher than that of the original coal body and 5.5 times higher than after the hydraulic-punching measures.

Keywords: "three-soft" coal seam, hydraulic punching, deep-hole pre-splitting explosion, unloading permeability improvement, gas extraction
\end{abstract}

Zaradi težav s slabo plinsko prepustnostjo, težavami z ekstrakcijo plina in slabo učinkovitostjo predekstrakcije plina treh mehkih plasti premoga na rudarskem območju Zhengzhou, Kitajska so avtorji tega članka analizirali tehnologijo kombiniranega hidravličnega prebijanja (punktiranja) in cepljenja plasti med miniranjem globokih vrtin. Analizirali so mehanizem dodatne penetracije med hidravličnim prebijanjem in nastajanja razpok z miniranjem globokih vrtin. Na osnovi dinamike eksplozij in lomne mehanike, so študirali, s pomočjo metod numerične simulacije, porazdelitev napetosti in napredovanje razpok v premogu zaradi eksplozij pri različnih razdaljah med vrtinami za namestitev eksploziva, ko so le-te prilagojene vrtinam za ekstrakcijo. Ugotovili so, da je primerna razdalja med dvema vrtinama za namestitev eksploziva $4 \mathrm{~m}$. Na preizkusnem polju rudnika Zhengzhou Coal Group - GC Coal, Zhongyuan, Zhengzhou na Kitajskem so ugotovili, da je učinek penetracije (prodiranja) po miniranju zelo pomemben, povprečna in maksimalna učinkovitost ekstrakcije plina v sosednjih štirih (4) skupinah je bila 0,065 $\mathrm{m}^{3} / \mathrm{min}$ oz. $0,11 \mathrm{~m}^{3} / \mathrm{min}$, kar je 2,5-krat in 5,5-krat več kot pred miniranjem in plinska prepustnost premoga poleg vrtin za eksploziv je bila $2,47 \mathrm{~m}^{2} /\left(\mathrm{MPa}^{2} \cdot \mathrm{d}\right)$, kar je 466-krat več, kot jo ima originalna premogova plast in 5,5-krat večja prepustnost, kot so jo izmerili po hidravličnem punktiranju.

Ključne besede: tri mehke plasti premoga, hidravlično punktiranje, priprava globokih vrtin pred miniranjem, izboljšanje neobremenjene prepustnosti, ekstrakcija plina

\section{INTRODUCTION}

The Zhengzhou mining area mainly includes the Shanxi Group No. 21 coal seam, which is a typical "three soft" coal-seam area in China with a low porosity, low permeability and high adsorption characteristics. ${ }^{1}$ The safety of the mine and the production-replacement ratio are seriously affected because of the poor coal-seam permeability and difficult gas extraction. ${ }^{2}$ Coal-mine gas disasters are tackled seriously at home and abroad. In order

*Corresponding author's e-mail:

lihui0391@aliyun.com (Hui Li) to improve gas drainage and coal-seam permeability, researchers from various countries put forward many methods, such as hydraulic flushing, hydraulic cutting, hydraulic fracturing, etc. By studying the applicability of different methods under various conditions of coal seams and comprehensively analyzing their advantages and disadvantages better technical methods can be selected and created. However, these methods have shortcomings.

In order to improve the permeability of the coal seam and realize an efficient gas extraction, the Zhengzhou Group carried out a lot of experimental researches on the underground coal mine. Practice shows that the hydraulic 
punching of the Rock Lane bottom plate is a more effective method of unloading the pressure and increasing the extraction for the "three soft" coal seam, but there are still several problems. Firstly, due to the soft-coal body of the No. 21 coal seam, the challenges of hole drilling, collapsing and plugging are serious. ${ }^{3-6}$ After intense hydraulic punching, the holes formed in the coal seam lead to a local stress concentration and an uneven pressure-relief effect, causing hidden danger for roadway supports in the later stage. ${ }^{7}$ Secondly, due to the poor permeability of coal seam 21 , the pre-pumping effect after hydraulic punching is still not ideal, and the gas concentration in the borehole attenuates rapidly. Generally, the gas concentration in 3-8 days after drilling is lower than $10 \%$ and even lower than $5 \%$ in some holes. With respect to the problems of anti-protrusion measures for the prepumping area of the "three soft" coal seam drilled with hydraulic punching in the Zhengzhou mining area, it became urgent to find whether it is possible to take secondary anti-reflection measures to further improve the permeability of the coal body between pre-drainage boreholes, without changing the original "hole-pipeseal-pumping" structure of the pre-pumping borehole of the penetration layer, in order to prolong the effective life span of the pre-pumping gas after the implementation of hydraulic measures, improve the gas pre-pumping effect and shorten the regional extinction-outburst period.

In recent years, deep-hole pre-splitting blasting, a technology for an effective improvemement of the permeability of a coal seam, has been widely used in the management of gas disasters in coal mines. ${ }^{8}$ At present, deep-hole pre-splitting blasting is mainly used with local anti-outburst technical measures; however, it is rarely studied, at home or abroad, as a technical measure to strengthen gas drainage and improve the drainage effect in a soft coal seam with low permeability. Based on this, the above authors put forward a penetration technology integrating hydraulic punching and deep-hole pre-splitting blasting, analyzing the mechanism of co-penetration of hydraulic punching and deep-hole pre-cracking blasting, the influences of different ways of blast-hole spacing on the blasting effect of deep-hole pre-cracking with a numerical simulation and determining the optimum spacing of blast drilling. ${ }^{9}$ An engineering experiment was carried out in the coal face of the 25031 Santa Yard of the GC coal mine in the Zhengzhou mining area, and the results showed that the permeability of the coal seam and the gas-pumping flow were effectively improved after the implementation of our synergistic penetration technology; a new way of exploring the gas treatment of a "three soft" low-permeability coal seam was started. ${ }^{10,11}$

\section{HYDRAULIC PUNCHING AND DEEP-HOLE PRE-SPLITTING BLASTING CO-PENETRATION MECHANISM}

The co-penetration technique of hydraulic punching and deep-hole pre-splitting blasting consists of drilling into the penetration layer of the construction of the Rock Lane bottom slab, and implementing the medium and high pressure. ${ }^{12}$ We use hydraulic punching for drilling, which ends after a period of continuous pumping, and a pre-splitting blast hole arranged between hydraulically punched boreholes so that the hydraulic punching for drilling and blast drilling form a cross-arrangement. Hydraulic punching forms a continuous plastic zone in the coal body. In particular, punching holes play a role in providing a free surface and a moving space for blast drilling; as a result, blasting after the induction of holes not only forms explosive fissures, but also promotes the displacement of coal bodies so as to achieve a regional pressure relief and permeability improvement.

\subsection{Induction effect of hydraulic punching on blasting}

Under the condition of a free surface, the stress wave produced by an explosive detonation propagates to the interior of the medium in the form of elastic waves. And when a stress wave propagates to the vicinity of a hydraulically punched hole, it immediately reflects back. Due to the tensile stress caused by reflected waves and weak discontinuous waves before and after, the range of cracks at the edge of hydraulically punched holes are further expanded and, at the same time, the radial cracks generated in the direction of the line connecting the blast holes are interpenetrated to form a penetration fracture surface of the blast holes and hydraulically punched holes. Since the fractures in the direction of the hydraulically punched holes occur earlier than those in the other directions, the fractures in this direction restrict the generation and development of the fractures in the other directions. So, in a sense, hydraulically punched holes are induced by radial fissures.

\subsection{Pressure relief and anti-reflection effect}

Under the action of blasting, blasting cavities are produced in the coal and rock mass, and internal cracks develop. The blast cavity is equivalent to an enlarged blast hole, releasing the ground stress and the high gas pressure around the blast hole so that the stress of the surrounding rock shifts to both sides of the borehole and reduces the high gas pressure around it. The coal and rock mass destroyed by the blast cavity formed by compression crushing reduces the potential energy contained in the coal rock mass and gas balance system, thus reducing the outburst risk. The most obvious function of a blasting fracture is to provide the circulation channel for the high-pressure gas. At the same time, each fracture also releases the pressure of the adjacent coal body, and under 
the action of seepage diffusion, the adsorbed gas is converted into free gas, thereby increasing the permeability of the coal body.

\section{NUMERICAL SIMULATION OF REASONABLE BLAST-HOLE SPACING}

\subsection{Numerical models and parameters}

In order to study the propagation and attenuation law of the explosion stress wave in the coal and rock mass and the influence of different ways of blast-hole spacing on the blasting effect, in accordance with the field working conditions, a numerical calculation model is established using finite-element-analysis software ANSYA/ LS-DYNA, as shown in Figure 1, and the dimensions in the model are presented in $\mathrm{cm}$.

The upper and lower sides of the model are non-reflective boundary conditions, while the front and rear boundaries of the model are loaded displacement constraints in the UZ direction. The sides of the model are blast holes and the middle is the control pumping hole.

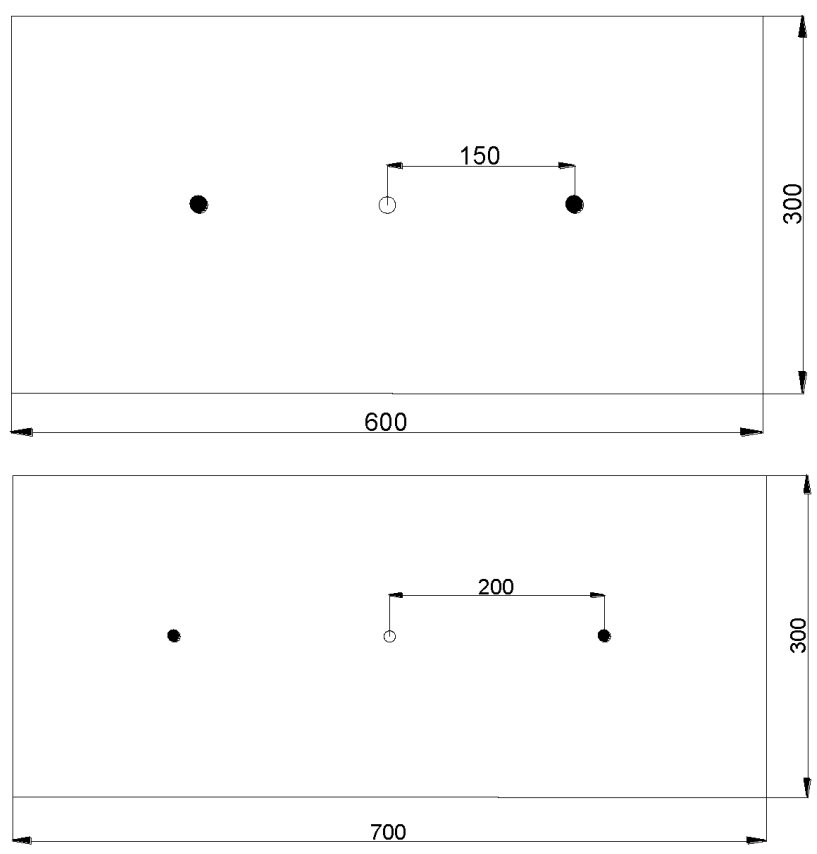

Figure 1: Numerical simulation model of deep-hole pre-splitting blasting: 1) simulation model with blast-hole spacing of $3 \mathrm{~m}, 2$ ) simulation model with blast-hole spacing of $4 \mathrm{~m}$
The calculation is not done when the simulation is performed. The blast holes are $1.5 \mathrm{~m}$ away from the boundary. Diameters of the blast holes and control extraction holes are $94 \mathrm{~mm}$, and the diameters of the medicine rolls are $75 \mathrm{~mm}$.

The JWL state equation in ANSYS/LS-DYNA can accurately describe the work process of the expansion of detonation products. From the equation, the detonation pressure acting on the detonation body at any time can be obtained, and the detonation pressure at any time is:

$$
P=A\left(1-\frac{\omega}{R_{1} V}\right) e^{-R_{1} V}+B\left(1-\frac{\omega}{R_{2} V}\right) e^{-R_{2} V}+\frac{\omega E_{0}}{V}
$$

In the formula, $A$ and $B$ are explosive characteristic parameters, Gpa; $R_{1}, R_{2}, \omega$ are dimensionless explosive characteristic parameters; $P$ is the pressure expressed in $\mathrm{kg} / \mathrm{m}^{2} ; E_{0}$ is the internal energy of a detonation product, $\mathrm{GPa} ; V$ is the relative volume of a detonation product, $\mathrm{m}^{3}$.

The mechanical-physical parameters of the coal seam and the basic parameters of the explosives in the simulation calculation are shown in Tables $\mathbf{1}$ and $\mathbf{2}$.

\subsection{Simulation-results analysis}

\subsubsection{Analysis of the stress changes to the coal bodies}

In the blasting process, the stress waves produced by blasting focus on the blast holes and spread in concentric circles to the surrounding coal bodies (Figures 2 and 3). The stress waves produced around two blast holes meet at a certain distance after the propagation, resulting in the superposition effect of the stress waves. Because of different distances between the two blast holes, the effects of the stress waves produced by the two blast holes, superimposed on each other, are also different. In Model 1, the stress waves meet at $2436.6 \mu$ s (Figure 2c). Then the stress waves produced by the two blast holes are superimposed on each other and spread continuously around them (Figure 2d). In Model 2, since the distance between the two blast holes is longer, the stress waves meet at $2934.1 \mu$ s (Figure 3d) and then spread toward each other, being superimposed.

In order to clearly analyze the variation law of the effective stress of the blasting-stress wave on a coal particle, a representative observation unit is selected on the lines connecting two blast holes to depict the curves of

Table 1: Parameters on mechanical-physical of coal seam

\begin{tabular}{|c|c|c|c|c|}
\hline Bulk weight $/\left(\mathrm{gcm}^{-3}\right)$ & $\begin{array}{c}\text { Elastic modulus } \\
/ \mathrm{GPa}\end{array}$ & Poisson's ratio & $\begin{array}{c}\text { Layer thickness of } \\
\text { primary rock } / \mathrm{m}\end{array}$ & $\begin{array}{c}\text { Compressive } \\
\text { strength } / \mathrm{MPa}\end{array}$ \\
\hline 1.4 & 2.62 & 0.2 & 4.5 & 7.32 \\
\hline
\end{tabular}

Table 2: Basic parameters of explosives

\begin{tabular}{|c|c|c|c|c|c|c|c|c|}
\hline \multirow{2}{*}{$P /\left(\mathrm{Kgm}^{-2}\right)$} & \multirow{2}{*}{$\begin{array}{c}\text { Blast speed } \\
v /\left(\mathrm{ms}^{-1}\right)\end{array}$} & \multicolumn{7}{|c|}{ JWL state equation parameters } \\
\hline & & $A(\mathrm{GPa})$ & $B(\mathrm{GPa})$ & $R_{1}$ & $R_{2}$ & $\omega$ & $R_{\mathrm{cj}} / \mathrm{GPa}$ & $E_{0}(\mathrm{GPa})$ \\
\hline 1620 & 6920 & 347 & 3.22 & 4.15 & 0.95 & 0.3 & 27 & 7.0 \\
\hline
\end{tabular}


P. LI et al.: TECHNOLOGY OF COUPLED PERMEABILITY ENHANCEMENT OF HYDRAULIC PUNCHING ...
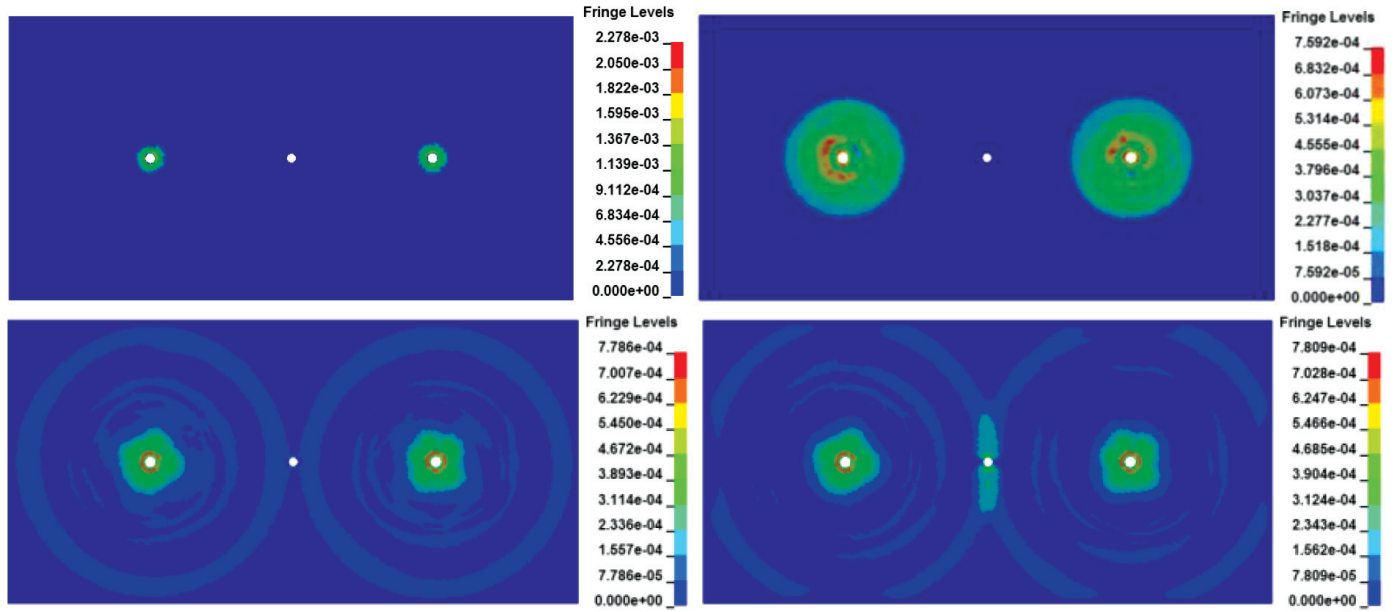

Figure 2: Stress cloud map of the coal body at the blast-hole spacing of $3 \mathrm{~m}$ : a) $t=427.13 \mu \mathrm{s}, \mathrm{b}) t=967.48 \mu \mathrm{s}, \mathrm{c}) t=2436.67 \mu \mathrm{s}, \mathrm{d}) t=2839.41 \mu \mathrm{s}$
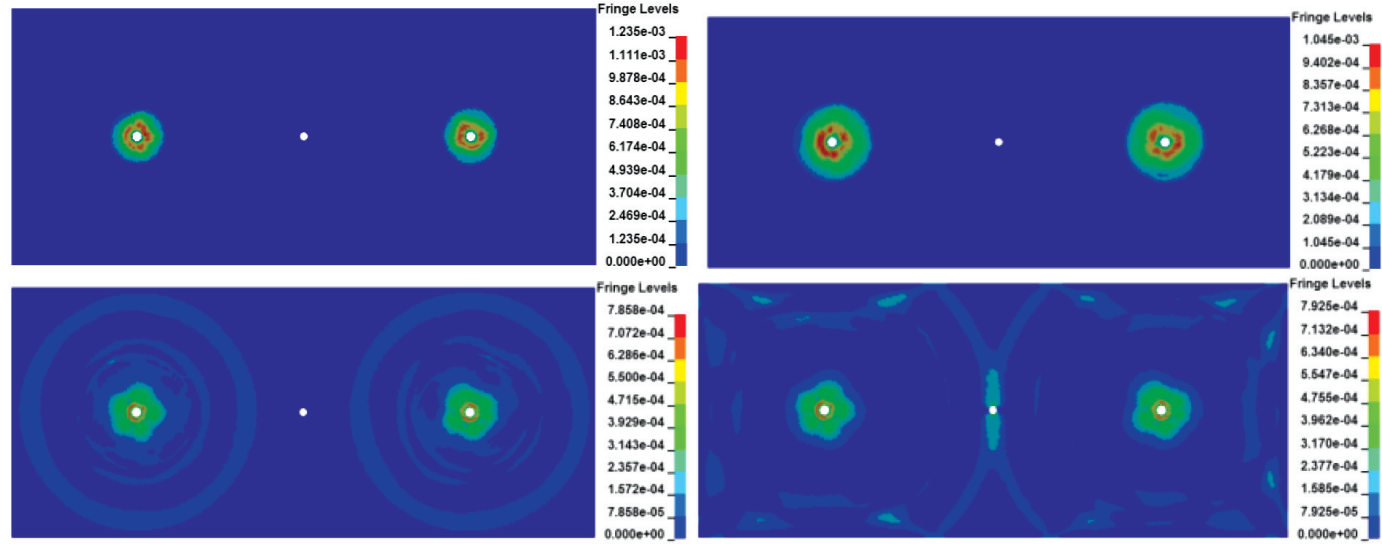

Figure 3: Stress cloud map of the coal body at the blast-hole spacing of $4 \mathrm{~m}:$ a) $t=562.24 \mu \mathrm{s}, \mathrm{b}) t=895.44 \mu \mathrm{s}, \mathrm{c}) t=2134.73 \mu \mathrm{s}$,
d) $t=2934.13 \mu \mathrm{s}$ d) $t=2934.13 \mu \mathrm{s}$

the effective stress changing with time, as shown in Figure 4.

When the blast-hole spacing is $3 \mathrm{~m}$, the observation units $(\mathrm{A}, \mathrm{B}, \mathrm{C})$ are set in the sequence $0.5,1,1.6 \mathrm{~m}$ from the left-hand blast hole

When the blast-hole spacing is $5 \mathrm{~m}$, the observation units $(\mathrm{A}, \mathrm{B}, \mathrm{C}, \mathrm{D})$ are set in the sequence $0.5,1,1.5,1.9$ $\mathrm{m}$ from the left-hand blast-hole

As can be seen from Figure 4, the detonation stress at a distance of $0.5 \mathrm{~m}$ from the blast hole increases rapidly after blasting and the maximum stress values reach $140 \mathrm{MPa}$ and $107 \mathrm{MPa}$, respectively, which is much larger than the tensile compressive strength of the coal body. The compression-crushing zone is formed here, and then the stress wave continues to propagate outward, while the stress value rapidly attenuates. At a distance of $1 \mathrm{~m}$ between the blast holes, the maximum effective stress values are $58 \mathrm{MPa}$ and $60 \mathrm{MPa}$, respectively, and the fractures continue to expand in this range. At distances of $1.6 \mathrm{~m}$ and $1.9 \mathrm{~m}$ between the blast holes, it is near the control extraction hole. It can be seen from the point curves in Figures $4 \mathbf{a} \mathbf{C}$ and $\mathbf{4 b} \mathbf{D}$ that the stresses of the two blast holes are superimposed to form a stress concentration, and the stress after the superposition

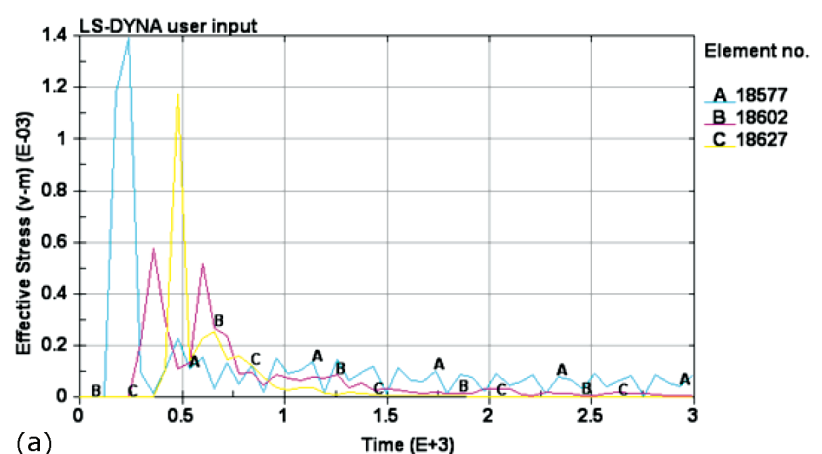

(a)

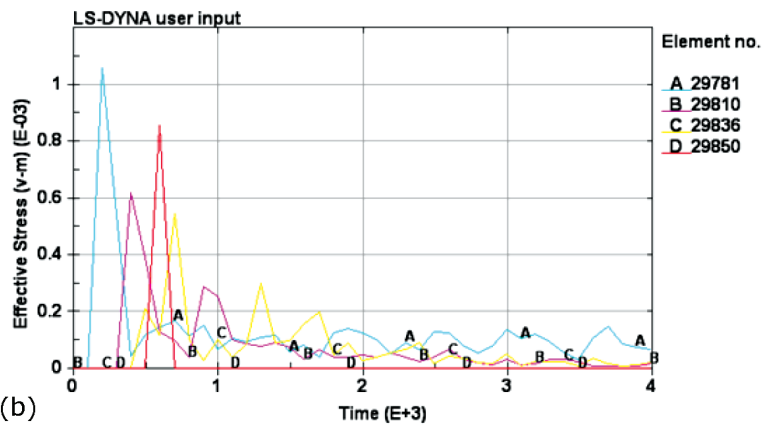

Figure 4: Effective stress distribution curves of each observation unit with a different blast-hole spacing 
P. LI et al.: TECHNOLOGY OF COUPLED PERMEABILITY ENHANCEMENT OF HYDRAULIC PUNCHING ...
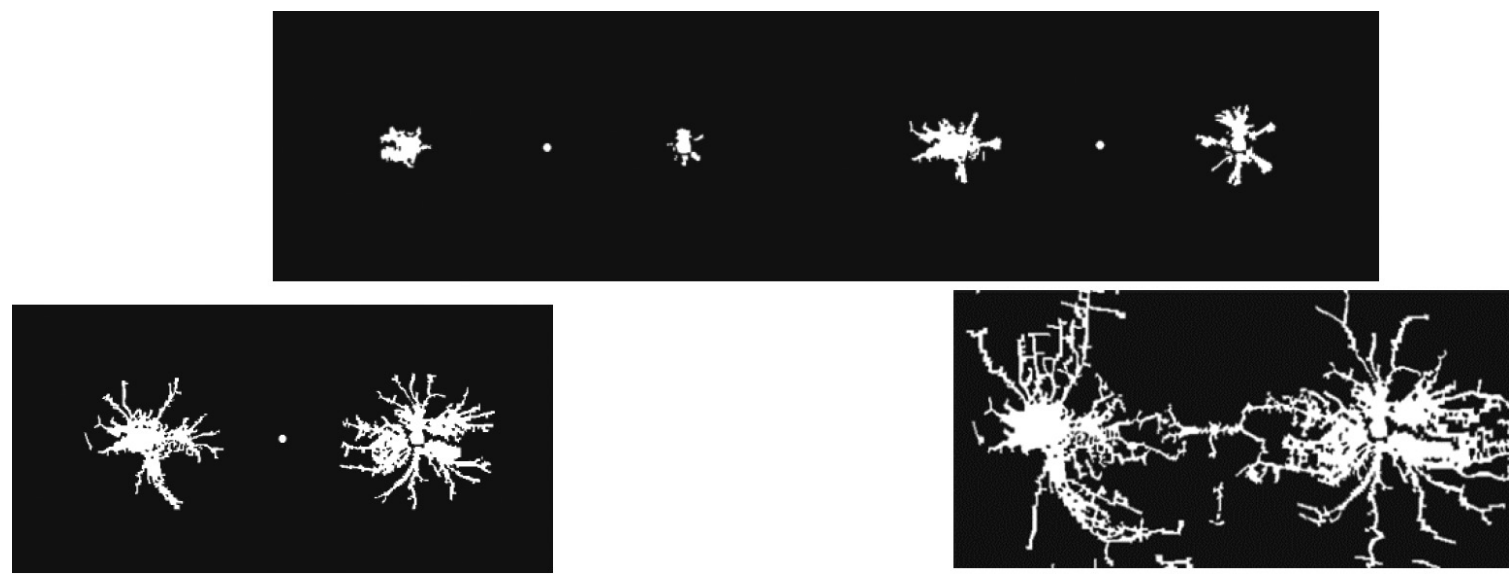

Figure 5: Generation and propagation of cracks at different times when the spacing of blast holes is $3 \mathrm{~m}:$ a) $t=769.33 \mu \mathrm{s}, \mathrm{b}) t=1048.57 \mu$, c) $t=1765.43 \mu \mathrm{s}$, d) $t=2667.26 \mu \mathrm{s}$
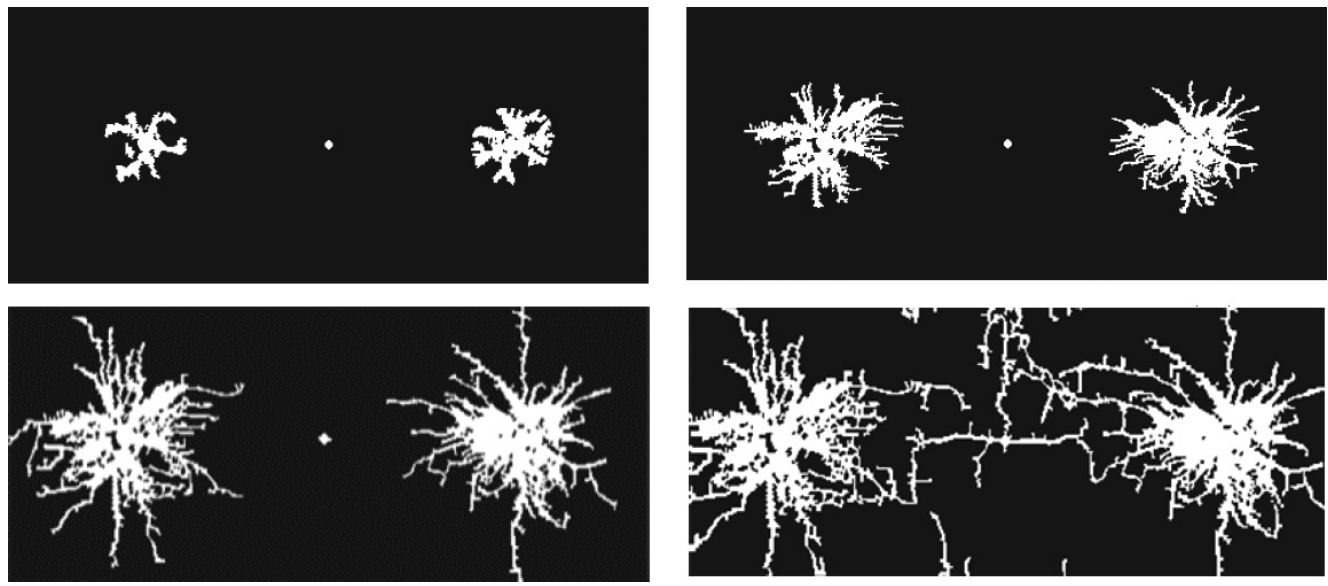

Figure 6: Generation and propagation of cracks at different times when the spacing of blast holes is $4 \mathrm{~m}$ : a) $t=913.91 \mu \mathrm{s}$, b) $t=1493.36 \mu$, c) $t=2357.92 \mu \mathrm{s}, \mathrm{d}) t=3026.33 \mu \mathrm{s}$

reaches $118 \mathrm{MPa}$ and $85 \mathrm{MPa}$, respectively, which indicates that the effective stress at the midpoint is larger for the shorter hole spacing.

\subsubsection{Analysis of a coal-crack propagation}

As can be seen from Figures 5 and 6, the interaction between the two models in the early stage of the crack propagation is very small and the crack growth is within the control range of the respective detonation gas. Due to the superposition of the stress waves and the drive of the detonation gas, the cracks perpendicular to the propagation direction of the stress wave begin to appear in Model 1 at $769.3 \mu$ s, and the coal fragmentation near the blast hole is accelerated. In Model 2, the cracks perpendicular to the stress-wave-propagation direction appear at $913.9 \mu$ s. In Model 1, the cracks generated by the two blast holes run through each other and are fully broken, enhancing the permeability of the coal body and having an obvious anti-reflection effect at $2667.2 \mu$ s. In Model 2 , due to the large distance between the two blast holes, the superposition effect of the two blast holes also decreases; as a result, the cracks produced by the two blast holes are unlikely to meet at an early stage. They meet and merge at $3026.3 \mu \mathrm{s}$.
Based on the repeated numerical simulation and comparative analysis, it is concluded that when the spacing between the two blast holes is $3 \mathrm{~m}$, the coal body is fully broken after blasting, the crack propagation is more rapid and the crack density is the largest, forming fractured nets that cross each other and provide enough channels for the gas migration into the coal body.

\section{FIELD TEST}

In order to investigate the penetration effect of deep-hole pre-cracking blasting through hydraulic punching under the condition of a controlled pumping hole, a field engineering test was carried out on the uncovered coal-mine face of Shimen, the substitute lane yard of the coal mine of Zhengzhou Coal Group, 25031, No. 188 Zhongyuan West Road, Zhongyuan District, Zhengzhou City. The coal-seam thickness of the uncovered coal area is $4.5 \mathrm{~m}$ and the gas content is 7.36-10.37 $\mathrm{m}^{3} / \mathrm{t}$. At the 25031 lower-bottom pumping-lane construction, upward perforation drilling of the pre-pumped stone of the coal-seam area was carried out for the coal-bed gas. According to the test result for the effective radius of gas extraction after hydraulic punching in the GC coal 


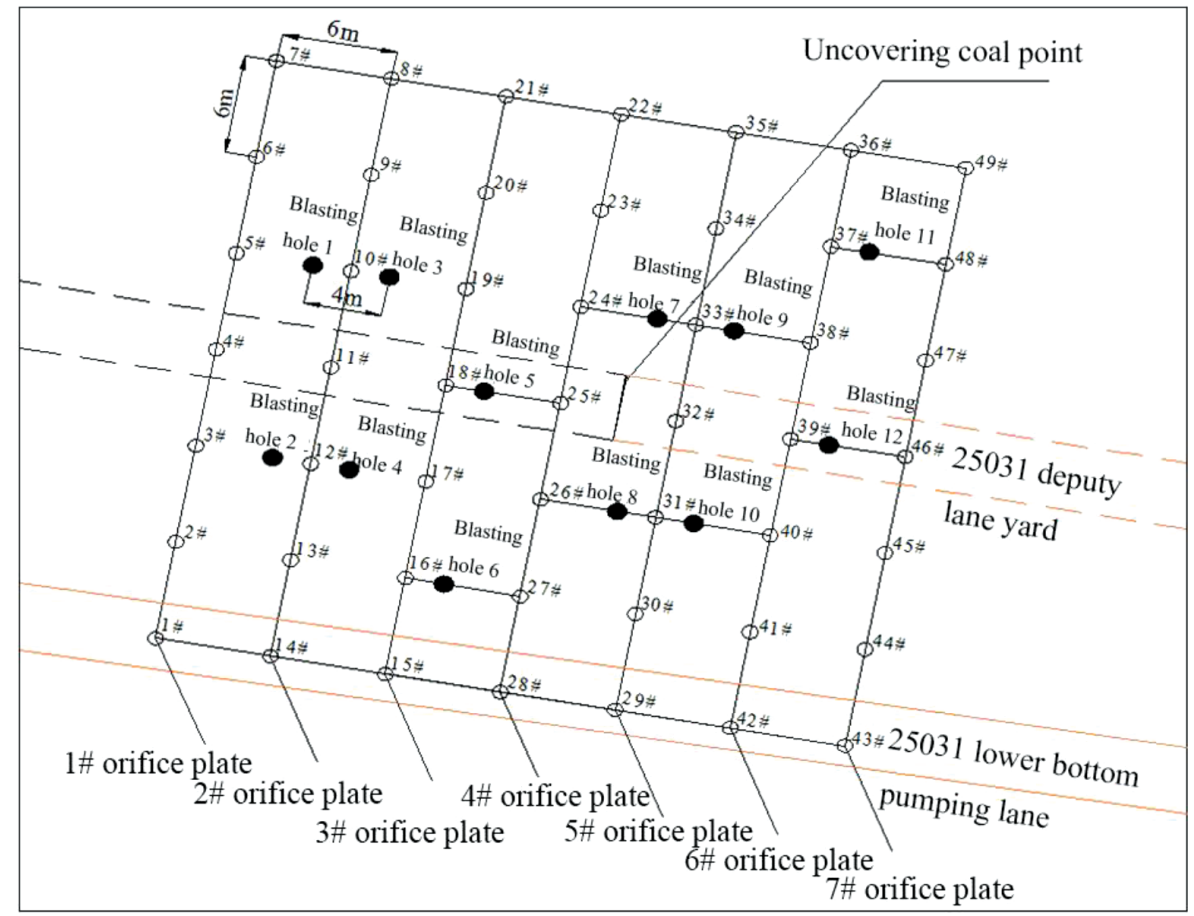

Figure 7: Diagram of the borehole layout in the test area

mine, that is, when the coal discharge quantity for a coal-hole section is at least $1.5 \mathrm{t} / \mathrm{m}$, the effective pumping radius of hydraulic punching is $3.5 \mathrm{~m}$ and the range of the hydraulic-punching coal leakage is $0.47-0.69 \mathrm{~m}$. At the same time, combined with the results for the section 2.2 blasting numerical simulation, the hydraulically punched holes in the test area are arranged according to a mesh arrangement of $6 \times 6 \mathrm{~m}$. The coal-drainage range of the hydraulically punched holes is $0.5 \mathrm{~m}$ and the distance between a blast hole and a hydraulically punched hole is $2 \mathrm{~m}$, that is, the distance between two blast holes is $4 \mathrm{~m}$. A total of 49 hydraulically punched boreholes and 12 blast boreholes were arranged in the test area, as shown in Figure 7. All the hydraulically punched and blast holes are $94 \mathrm{~mm}$ in diameter.

\subsection{Construction process of the synergistic penetra- tion-enhancement technology}

The implementation of punching and blasting synergistic penetration-enhancement technology is divided into two stages: hydraulic punching and blasting. The steps are as follows:

- Firstly, drilling is used to cross the holes according to design requirements.

- Hydraulic punching is carried out on a crossing hole with a large dip angle.

Drilling adopts a low water pressure and the large-flow mode for punching holes, and controls the single-hole-leakage coal volume. Large-dip-angle drilling adopts a low water pressure and the large-flow-mode punching to control the single-hole-leakage coal volume. Plain holes adopt a high water pressure, the small-flow- mode punching or an extended punching time to improve the single-hole coal leakage. The amount of the coalhole leakage per meter should not be lower than $1.5 \mathrm{t}$, and the amount of the single-hole coal should not exceed $30 \%$ of the designed coal leakage.

3) At the end of punching, all the boreholes are connected to the extraction pipeline for a week, and the blasting-drilling construction is carried out according to the design. Using the method of loading 1-2 medicine rolls each time, the length of a single-hole charge is 6-10 $\mathrm{m}$ and the length of the bottom-hole rock section is not below $3 \mathrm{~m}$. The pre-cracking blasting-sealing equipment is used for sealing, and detonating is performed after the sealing is completed. First, the holes with Nos. 1-6 are blasted, and the construction blasting of the holes with Nos. 7-12 is carried out after an inspection.

\subsection{Effect assessment of the synergistic penetration-en- hancement technology}

\subsubsection{Gas-extraction concentration and a flow analysis}

At the end of the blasting operation, the changes in the pumping concentration and flow rate for each orifice plate with time are obtained by testing and monitoring. As an example, Figure 8 shows the variation in the gas concentration and flow with time before and after the blasting of $1 \#-4 \#$ orifice plates after blasting holes with Nos. 1-6.

As can be clearly seen from the figure above, after the detonation of 1-6 blast holes, the gas concentration and flow rate for $1 \#-4 \#$ orifice plates increase. The gas concentration of $2 \#$ orifice plate averagely increases 3.6 times in the 7 days after blasting compared with the pre- 


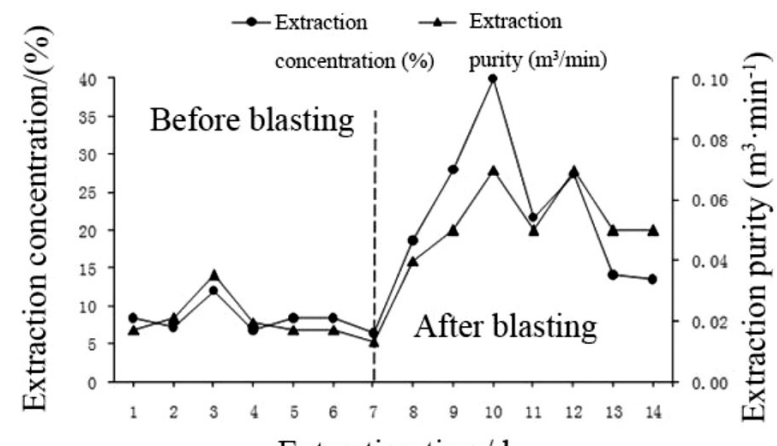

Extraction time/d

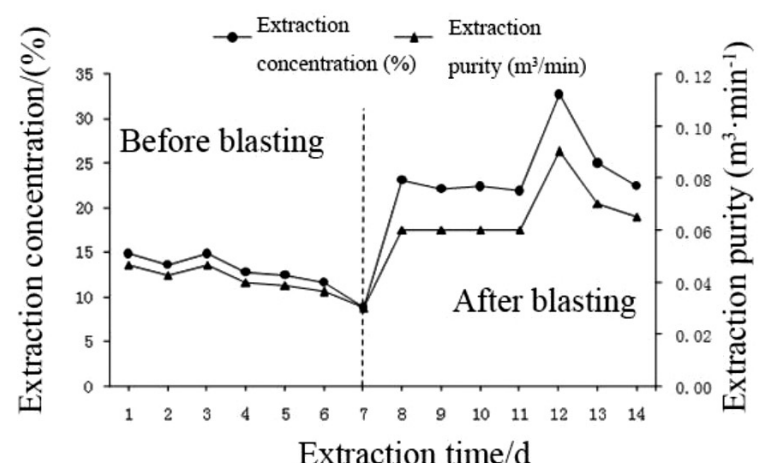

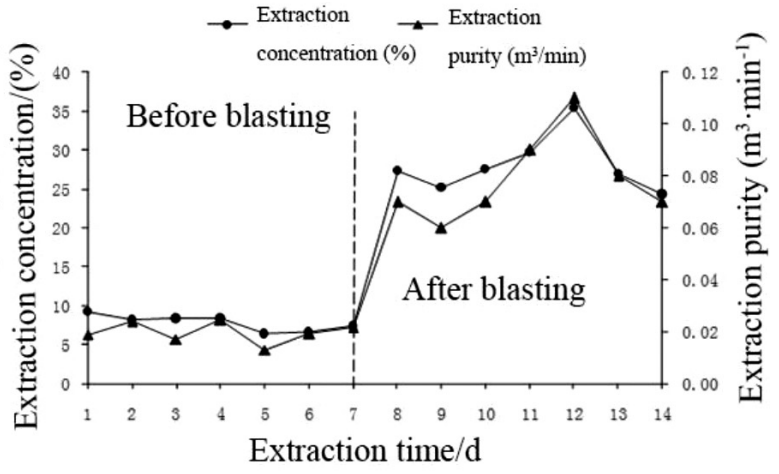

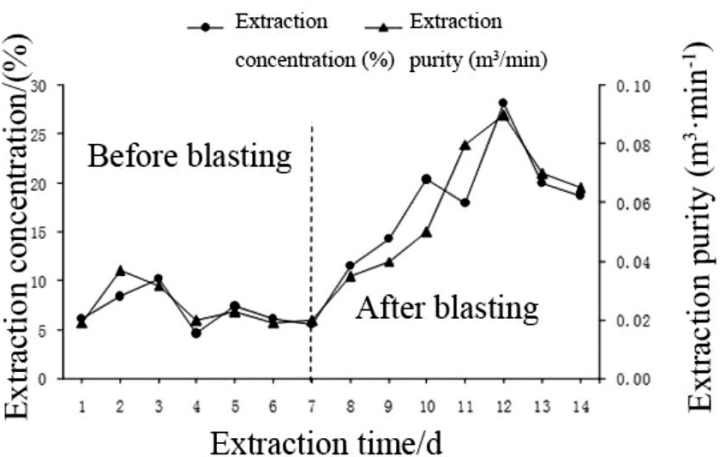

Figure 8: Variation curves for the purity and concentration of gas drainage from 1\#-4\# hole plate before and after blasting

Table 3: Comparative analysis of hydraulic punching and deep-hole pre-cracking effect before and after blasting

\begin{tabular}{|c|c|c|c|}
\hline Parameter & Before punching & After punching & After collaborative blasting \\
\hline $\begin{array}{l}\text { Coal-seam permeability coefficient } \\
\lambda /\left(\mathrm{m}^{2}(\mathrm{MPad})^{-1}\right)\end{array}$ & 0.0053 & 0.45 & 2.47 \\
\hline
\end{tabular}

vious state, and the concentration of extraction becomes stable at $24.3-35.4 \%$. The extraction concentrations of $1 \#$ orifice plate and $3 \#$ orifice plate increase 2.83 and 2.7 times, respectively, compared with the concentration before blasting. As the drilling construction has a significant effect on the coal-rock loosening, 4\# orifice plate exhibits a higher gas concentration within the 7 days after blasting. And it also averagely increased 1.9 times compared with the previous state. Finally, the gas concentration of an orifice plate goes up and down at $20 \%$. The gas purity of $2 \#$ orifice plate peaks on the 5 th day after the detonation, which is an increase of 5.5 times of the average gas purity before the blasting. Under the action of blasting, the gas purity of $1 \#$ orifice plate and $3 \#$ orifice plate is 3.5 and 4.5 times higher than before. The gas purity of $4 \#$ orifice plate is much better than that of the other plates before blasting, and it is stable at the original level after the blasting; on the 5th day it reaches an increase of 2.3 times. There is no significant change in the gas-extraction concentration and extraction purity of $5 \#$ orifice plate after blasting.

\subsubsection{Coal-permeability variation}

Based on the above-mentioned punching and synergistic gas-absorption data, the gas-permeability coefficients of the No. 21 coal seam before and after hydraulic punching and blasting were determined with the radial unstable flow method (Table 3).

It can be seen from Table 3 that the original gas-permeability coefficient of the coal seam is $0.0053 \mathrm{~m}^{2} /\left(\mathrm{MPa}^{2} \mathrm{~d}\right)$. After the hydraulic-punching measures, it increases to $0.45 \mathrm{~m}^{2} /\left(\mathrm{MPa}^{2} \mathrm{~d}\right)$, which is an increase of 85 times. After the blasting measures are taken, it increases to $2.47 \mathrm{~m}^{2} /\left(\mathrm{MPa}^{2} \mathrm{~d}\right)$, which is an increase of 466 times compared with the original coal body and 5.5 times compared with the hydraulic-punching measures.

\section{DISCUSSION}

In order to clearly analyze the variation law of the effective stress of the blasting wave on coal particles, representative observation units are selected on the blasting-hole connecting lines to depict the curves of the effective-stress changing with time, as shown in Figure 4. As can be seen from Figures 5 and 6, the interaction between the two models in the early stage of the crack-propagation phase is very small, and the crack growth is within the control range of the respective detonation gas. It is concluded that when the spacing between two blast holes is $3 \mathrm{~m}$, the coal body is most fully 
broken after blasting, the crack propagation is more rapid and the crack density is the largest.

\section{CONCLUSIONS}

1) In this research, aiming at the problems of "three-soft" coal seams with poor permeability and low gas drainage, taking the Zhengzhou coal mine as an example, we found many disadvantages of the hydraulic-punching technology when used alone. Practice shows us that the pre-splitting blasting technology can improve these problems significantly and can help us improve the coal-seam permeability and gas drainage. Through the application of a numerical-simulation analysis, combining hydraulic punching and blasting, the experimental data demonstrated the feasibility and outstanding role of the combination of the two processes, allowing us to realize the theoretical analysis of the practicality and mechanism of the technology.

2) Hydraulic punching of holes has an obvious induction-promoting effect on the development of deep-hole bursting ruptures, while blasting can use the free surface provided by a hydraulically punched hole so that the gap network between the two holes is greatly connected, improving the permeability of the coal seam.

3) By comparing and analyzing the numerical-simulation results, it becomes clear that the detonation shock wave generated by the explosion can cause crack expansion around the coal body, realizing the effect of coalseam penetration enhancement. When the effective stress wave is transmitted to the control extraction hole, the stress wave forms a stress concentration at the extraction hole. The effective-stress value is greater than the tensile compressive strength of the coal rock mass around the pumping holes, promoting the formation of more cracks in the coal rock mass around the pumping holes, and the control extraction holes obviously play a role in the fracture expansion in the coal rock mass. If the control extraction hole is not punched, it is determined that the distance between the blast hole and the control extraction hole is $1.5 \mathrm{~m}$. In short, the blasting effect is better when the distance between the two blast holes is $3 \mathrm{~m}$.

4) Field tests show that after hydraulic penetration and deep-hole pre-splitting blasting, the synergistic anti-reflection technology is implemented, the coal-seam penetration improvement and pressure relief are realized, and the effect of gas extraction is apparent. After blasting, the gas permeability of the coal body is 466 times larger than that of the primitive coal body and 5.5 times larger than that of the coal body after hydraulic punching, while the average pure amount and maximum flow of gas extraction are 2.5 times and 5.5 times larger than before blasting, respectively.

5) As the research on the hydraulic punching technology and blasting technology is scarce at home and abroad, the research on this kind of technology, included in this paper, has an academic value and guiding value in the world, which requires a technical method to solve the problems of poor permeability and low gas extraction from "three-soft" coal seams as well as the theoretical basis for the application of this kind of technology.

The experiment from this research is mainly based on the Zhengzhou coal mine. The experimental data and results have certain limitations while the theoretical results lack universal applicability. In the future, the research scope should be broadened and sampling methods should be selected appropriately. Then, the experimental results should be compared and analyzed. In addition, the pre-splitting blasting technology for "three-soft" coal seams is difficult to operate due to the softness of coal seams, so relevant research should be carried out to improve the technical method.

\section{REFERENCES}

${ }^{1}$ Z. Wang, S. Li, Y. Wang, Characteristics of compression fracture of "three soft" coal bed by perfusion and gas sucking technique, J. Coal Sci. Eng. China, 17 (2011), 43-46

${ }^{2}$ X. F. Wang, D. S. Zhang, G. J. Li, T. Ren, X. D. Wang, Boreholes layout of coal mine methane drainage for high gassy and low permeability coal seams in Tiefa coal-field, J. China Coal Soc., 36 (2011) 8, 1296-1330

${ }^{3}$ S. Q. Sun, Q. Zhang, Z. M. Yan, J. Zhang, Y. W. Wang, K. G. Zheng, Practice of permeability enhancement through overall hydraulic fracturing of long hole in outburst-prone soft crushed coal seam with low permeability, J. China Coal Soc., 42 (2017) 9, 2337-2344

${ }^{4}$ Y. Wang, X. He, E. Wang et al., Research progress and development tendency of the hydraulic technology for increasing the permeability of coal seams, J. China Coal Soc., 39 (2014) 10, 1945-1955

${ }^{5}$ B. X. Huang, C. M. Huang, Q. Y. Cheng, C. H. Huang, W. C. Xue, Hydraulic fracturing technology for improving permeability in gas-bearing coal seams in underground coal mines, J. South Afr. Inst. Min. Metal., 112 (2012), 485-495

${ }^{6}$ C. Zhai, B. Q. Lin, X. Z. Li, Q. G. Li, M. B. Zhang, W. Yang, C. Zhang, A method for increasing permeability of coal seam using pulse hydraulic fracturing, Inventive Patent (2011b), China

${ }^{7}$ B. Q. Lin, Q. Z. Zhang, C. M. Shen, W. Yang, Permeability-increasing mechanism of network slotting boreholes and application in crossing borehole gas drainage, J. China Coal Soc., 37 (2012) 9, 1425-11430

${ }^{8}$ K. Wang, B. Li, J. P. Wei, P. Li, Change regulation of coal seam permeability around hydraulic flushing borehole, J. Mining Safety Eng., 30 (2013) 5, 778-784

${ }^{9}$ F. Cai, Z. Liu, B. Lin et al., Numerical simulation and experiment analysis of improving permeability by deep-hole pre-splitting explosion in highly gassy and low permeability coal seam, J. Coal Sci. Eng. China, 15 (2009), 175-180

${ }^{10}$ H. D. Wang, Application and Analysis of Deep Hole Pre-splitting Blasting in Low Permeability and High Outburst Coal, J. China Safety Sci., 21 (2011) 11, 72

${ }^{11}$ S. Cao, Y. Li, Y. Liu et al., Effectiveness analysis of methane-drainage by deep-hole controlled pre-splitting blasting for preventing coal and gas outburst, J. Coal Sci. Eng. China, 15 (2009), 166-170

${ }^{12}$ D. M. Zhang, X. Bai, G. Z. Yin et al., Research and application of technology of increased permeability by liquid $\mathrm{CO} 2$ phase change directional jet fracturing in low-permeability coal seam, J. China Coal Soc., 43 (2018) 7, 1938-1950 